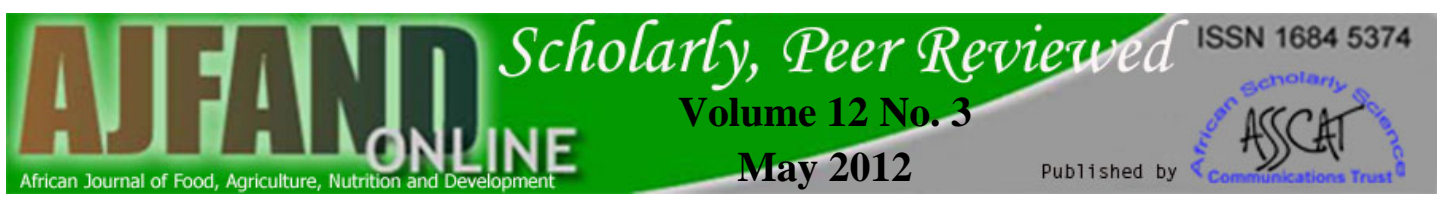

\title{
ASSESSING THE IMPACT OF CREDIT CONSTRAINTS ON FARM HOUSEHOLD ECONOMIC WELFARE IN THE HINTERLAND OF KINSHASA, DEMOCRATIC REPUBLIC OF CONGO
}

\section{Muayila $\mathrm{KH}^{* 1}$ and E Tollens ${ }^{1}$}

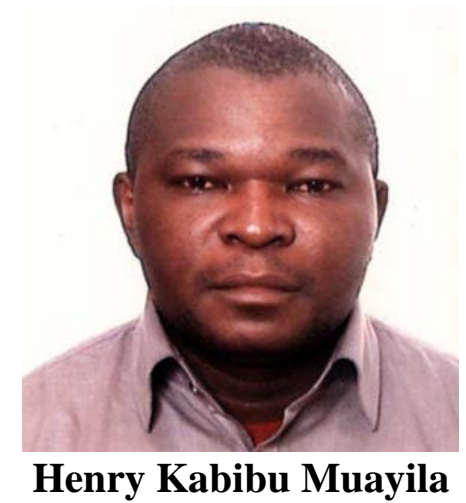

*Corresponding author email: henri_muayila@yahoo.fr

${ }^{1}$ Centre for Agricultural and Food Economics, Faculty of Bioscience Engineering, Katholieke Universiteit Leuven, Celestijnenlaan 200 , Box 241, 3001 Heverlee, Belgium 


\section{ABSTRACT}

This study investigates the impact of credit constraints on farm household economic welfare. Data were cross sectional and collected at household level in the Hinterland of Kinshasa, Democratic Republic of Congo. The sample survey consists of 202 farm households randomly selected. The survey was conducted from February to March 2008. The non-parametric method known as the Propensity Score Matching was applied to compute the impact of credit constraints on farm household welfare. The credit constraints were identified based on direct questions to households about their credit status. The household economic welfare was measured using the consumption approach. The results from descriptive statistics establish the existence of high level of credit constraints among farm households in the area of study. The majority of farm households (71\%) have to endure credit constraints. The results of descriptive statistics indicate that the lack of collateral, the loan terms conditions, the credit technology, the higher level of agricultural risks, the high interest rates and the low returns on farming activities explain the limited access to credit by farmers. The results of logit model show that household social capital, household access to remittances, household land holding and household access to extension service tend to reduce the probability of being credit constrained, while the household size tends to increase the propensity of being credit constrained. The results of the propensity score matching report that credit constraints reduce per capita food consumption per day from -197 FC to -219 FC (-0.35\$ to $-0.39 \$)$. The impact of credit constraints on per capita non-food consumption per day is quite difficult to be supported. The results report that only ATT obtained from Radius estimator shows a negative and significant effect at $\mathrm{p}<0.010$. The average effect of credit constraints on per capita total consumption per day is estimated at about -328 FC $(-0.59 \$)$ under Radius matching, -269FC (-0.48 \$) under Kernel matching and -280 FC (-0.50\$) under Stratification matching. The average impact on the ratio of per capita total consumption per day to poverty line of $1 \$$ and to poverty line of $2 \$$ ranges from -0.59 to 0,48 and from -0.29 to -0.23 , respectively. The study concludes that the improvement of farm household access to credit could result in increasing economic welfare.

Key words: Credit Constraints, Farm Household, Welfare 


\section{INTRODUCTION}

Despite its large and various natural resources, the Democratic Republic of Congo (DRC) remains one of the poorest countries in the world. Poverty in DRC has become a phenomenon of mass. However, the incidence, the depth and the severity of poverty are higher in the rural areas rather than in the urban areas [1, 2, 3, 4]. The credit constraints as a result of the market imperfections have been recognized as one of main constraints to the improvement of farm household welfare in the periphery of Kinshasa [1,2]. The literature argues that a more efficient provision of financial services is welfare improving because of several reasons: the access to credit may affect household decisions and welfare distribution through the consumption smoothing, the income enhancement and smoothing, the risk-coping effect, the liquidity effect and the income and wealth effect $[5,6,7,8,9]$. This construction has been supported by many previous empirical studies $[10,11,12,13,14,15,16]$. This paper is an assessment of credit constraints' impact on the economic welfare of households in the Hinterland of Kinshasa. Thus, two questions are addressed: What are the main determinants of household credit constraints? How much and in which direction do credit constraints affect the economic welfare of credit constrained households?

\section{MATERIALS AND METHODS}

The study was conducted in the Hinterland of Kinshasa, which consists of all the neighborhoods of the green belt of Kinshasa. Given the lack of reliable data, the first step of the survey consists of carrying out the accounting of the households per village. The sample is made by a quota with a rate of $15 \%$ per village. The survey related household survey was conducted in villages located in the area between Menkao, Dumi and Mbankana, where Téké represent the main share of the population. Three groups of villages have been selected for the survey. The first group includes Menkao, Bita and Kingankadi. The second consists of Dumi, Mutiene and Isolo. The last one comprises Mbankana, Cité-CADIM and Kinzono. To simplify the analysis and given the small size of the sample, these groups are named, respectively Menkao group, Dumi group and Mbankana group. The sample consists of 202 households randomly selected from each village. A structured questionnaire is used to obtain data. It consists of questions regarding household characteristics, including the age, the gender and the education of the head of household, the off-farm activities, the social capital as well as the household consumption. The survey was conducted from February to March 2008. The credit constraints were identified based on direct questions to households about their credit status.

Assessing the impact of credit constraints on the economic welfare of constrained households requires the comparison of the observed outcome of constrained households (welfare indicators) with the outcome that would have resulted if they were not constrained. However, only one outcome is observed. This is known in the literature on the impact evaluation as counterfactual problem $[17,18]$. If the credit constraints were random, one could compute their effects by comparing the average outcome of constrained households with that of unconstrained households. This is

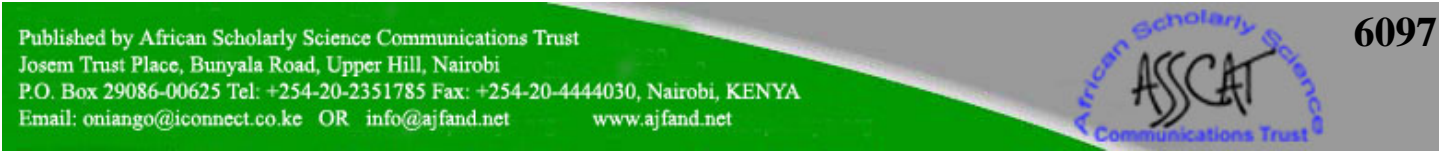




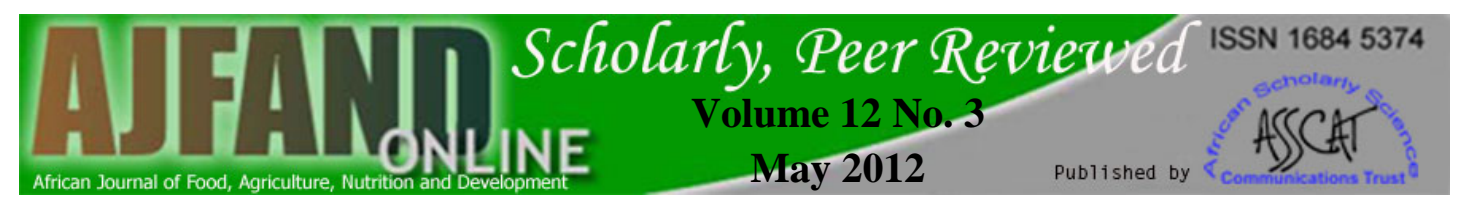

only possible and reliable in natural experimental observations. Furthermore, because household credit status is not random, the simple comparison of the average outcome of both groups is not appropriate and could lead to an over estimation of the impact. Therefore, given the non experimental nature of the data set used in this study and the counterfactual problem (missing data), the Propensity Score Matching (PSM) is applied to estimate the impact of credit constraints on the welfare distribution of the constrained households. By applying PSM, it is assumed that being credit constrained could be similar to a "treatment". Thus, the Average Treatment Effect on Treated (ATT) may be estimated as a proxy of impact of credit constraints on constrained households.

Following Becker and Ichino [17], the propensity score of being credit constrained $P(z)$ is defined as a conditional probability given a set of observable characteristics of households $(z)$. Furthermore, it is assumed that the probability of being credit constrained ranges between 0 and 1 , which means that $(0 \prec P(z) \prec 1)$; and may be obtained by computing $P(z)=\operatorname{Pr}\left(C_{i}=1 / z\right)=E(C / z)$. It is also assumed that if the exposure to credit constraints is random within cells defined by $\left(z_{i}\right)$, it is also random within cells defined by $P(z)$. The propensity score may be estimated using either logit model or probit model. After the estimation of propensity score of being credit constrained, the next step is then to compute the Average Treatment Effect on Treated (ATT) or the average impact of credit constraints on the economic welfare of constrained households. Then, ATT may be computed by calculating the following equation:

$$
\begin{aligned}
A T T & =E\left[W_{1 i}-W_{0 i} / C_{i}=1\right] \\
& =E\left[E\left(W_{1 i}-W_{0 i} / C_{i}=1, P(z)\right)\right] \\
& =E\left\{E\left\{W_{1 i} / C_{i}=1, P(z)\right\}-E\left\{W_{0 i} / C_{i}=0, P(z)\right\} / C_{i}=0\right\}
\end{aligned}
$$

Where $W_{1 i}$ and $W_{0 i}$ are sets of household welfare indicators for constrained households (treatment group) and unconstrained households (control group), respectively. For empirical estimation, household economic welfare is measured by the per capita household total consumption per day (TCONSDP), the per capita household food consumption per day (FOODPD), the per capita household non food consumption per day (NFOODPD), the ratio TCONSDP to poverty line (1\$) and the ratio TCONSDP to poverty line (2\$). The treatment variable $C$ defines household credit status, which is a binary choice taking value 1 if a given household faces credit constraints and 0 otherwise. $Z$ is a set of conditional variables or observable household characteristics assumed to be potentially associated with credit status. Different household socioeconomic characteristics are selected, including the household size (HHSIZE), dependency ratio (DRATIO), the age of household head (HHAG), the household head education (EDUCHH), the gender of household head (HHMAL), the household participation into off-farm activities (OFFFARM), the access to the extension services (EXTENSION), the regular household access to remittances (REMITTANCE), the

Published by African Scholarly Science Communications Trust
Josem Trust Place, Bunyala Road, Upper Hill, Nairobi
P.O.Box 29086-00625 Tel: +254-20-2351785 Fax: +254-20-4444030, Nairobi, KENYA
Email: oniango@iconnect.co.ke OR info@ajfand.net $\quad$ www.ajfand.net


household land holding property (LANDPROPERTY), the household size (HHSIZE), household participation into social and economic organizations (ASSOCIATION) and household location (MBANKANA, DUMI and MENKAO).

As the propensity score is a continuous variable, it becomes fairly hard to expect a lot of observations within the same region, thus, the exact matching is not possible. Furthermore, the estimated ATT may be sensitive to the choice of matching techniques or different neighborhoods. To avoid this problem and following Becker and Ichino [17], different matching techniques are implemented, such as Nearest Neighbor matching, Radius matching, Kernel matching and Stratification matching. In the Nearest Neighbor matching, each unit of credit constrained group is matched to an unconstrained unit using the closest propensity score. While in the Radius matching, constrained households are only matched with unconstrained households within a range of propensity scores. Within Kernel matching, the propensity score of each constrained unit is matched with the Kernel weighted average outcome of all unconstrained units. Finally, with Stratification matching, the range of variation of the propensity score is divided into intervals such that within each interval constrained and unconstrained households have on average the same propensity score.

The p score computer program, developed by Becker and Ichino [17] and prepared as a Stata software application was applied for empirical estimation of ATT. The first step is the estimation of propensity score of being credit constrained using logit model. The dependant variable is household credit status, which is assumed to be equal to 1 if household faces credit constraints and 0 otherwise. The explanatory variables are household characteristics and village of residence. After the estimation of propensity score, the next step is to compute the Average Treatment Effect on Treated (ATT). However, before generating ATT, it was ensured that the sample is comparable and the estimation is restricted to the observations within the region of common support, which is the area where there are sufficient observations of both groups. Households without comparable values in the other group are excluded before the estimation of ATT.

\section{RESULTS}

The results of the survey indicate that $38 \%$ of households did not apply for a loan because of several reasons and thus are considered as being credit constrained. The lack of collateral (79\%), inappropriate terms /conditions of loans provided by local financial organizations (83\%), small amount of credit provided by local lenders which is inappropriate to the need of agriculture (76\%), high risks related to the agricultural activities (71\%), high interest rate applied by lenders (71\%) and low returns on farming activities (78\%) are the main reasons mentioned by farmers to explain why they did not apply for a loan. In addition, 3\% of households did not apply for credit because they did not need credit and, therefore, were classified as credit unconstrained. About $59 \%$ of households from the sample applied for credit, 26\% received the total amount of the loan requested, $22 \%$ did not receive the total amount applied, and $11 \%$ did not receive anything. Thus, $71 \%$ of households from the sample were credit constrained.

Published by African Scholarly Science Communications Trust
Josem Trust Place, Bunyala Road, Upper Hill, Nairobi
P.O. Box 29086-00625 Tel: +254-20-2351785 Fax: +254-20-4444030, Nairobi, KENYA
Email: oniango@iconnect.co.ke OR info@ajfand.net www.ajfand.net


Tables 1 and 2 report the distribution of household socio-economic characteristics with respect to status credit constraints. The results show that household participation in off-farm activities, household participation in social and economic associations, regular access to remittances, household holding property, household access to extension services and household size are associated with credit status. Table 3 reports the descriptive distribution of a set of household welfare indicators obtained from the survey. The results from table 3 show an important gap in welfare distribution between constrained and unconstrained households. The average difference is about 428 FC for the per capita total household consumption per day, 196 FC for the per capita non-food consumption per day, 232 FC for the per capita food consumption, 0.764 for the ratio of the per capita total consumption per day to poverty line (1\$) and 0.382 for the ratio of per capita total consumption per day to poverty line (2\$). The difference in means of welfare distribution between unconstrained and constrained households is significant at p $>0.000$ for all selected indicators.

Table 4 reports the results of logit model used to estimate propensity scores of being credit constrained, while table 5 presents the distribution of these propensity scores. The results from table 4 show that the existence of off-farm activities within households, household participation in social and economic organizations, the regular access to remittances, land holding, access to extension services affect negatively the probability of facing credit constraints. The size of household is positively associated with the propensity of being credit constrained. However, credit constraints are not significantly associated with the dependence ratio, the formal education of household head, the age of household head, the gender of household head and the village of residence.

Once the propensity score of being credit constrained was estimated for each household from the sample, the balancing condition was checked and found satisfied. Before generating the average impact of credit constraints on the welfare of constrained households or ATT, the common support region was computed. Table 6 presents the impact of credit constraints on the welfare of constrained households.

In light of the results of table 6, one notes that on the average, credit constraints conditions have a reducing effect on per capita food consumption per day, ranging from -197 FC(-0.35\$) to -219 FC (-0.39\$). Under minimalist hypothesis, the average impact of credit constraints on per capita food consumption per year could be estimated at about $-130 \$$. The effect on food consumption is significant for all matching estimators, but with different thresholds of significance. The ATT garnered is significant at about $\mathrm{p}<0.010$ for Nearest Neighbor matching; $\mathrm{p}<0.005$ for Kernel and Stratification matching; and $\mathrm{p}<0.001$ for Radius matching. The Radius matching estimator provides the maximum value of ATT, whereas the Nearest Neighbor furnishes the minimum value of ATT.

Using food consumption as an outcome variable, the impact of credit constraints on per capita non-food consumption per day is quite difficult to be supported. The result reports that only ATT obtained from Radius estimator show negative and significant effect at $\mathrm{p}<0.010$. Radius ATT is estimated at about -110 FC (- 0.20\$). However,

Published by African Scholarly Science Communications Trust
Josem Trust Place, Bunyala Road, Upper Hill, Nairobi
P.O. Box 29086-00625 Tel: +254-20-2351785 Fax: +254-20-4444030, Nairobi, KENYA
Email: oniango@iconnect.co.ke OR info@ajfand.net $\quad$ www.ajfand.net


ATT obtained from Kernel, Nearest Neighbor and Stratification estimators despite being affected by a negative sign are not significant.

Considering total consumption as an interest variable, the results reported in table 6 show that credit constraints reduce per capita total consumption by about 328 FC (0.59\$) per day under Radius method, 269FC (0.48 \$) under Kernel method and 280 FC (0.50\$) under Stratification method. The ATT is significant at about $\mathrm{p}<0.001$ under Radius and Stratification matching, whereas it is significant at $\mathrm{p}<0.005$ under Kernel. Thus, it ensures that the average effect of credit constraints on per capita total consumption for constrained households can be valued close to - $215 \$$ per year. However, although the ATT obtained from Nearest Neighbors matching shows a negative effect estimated at about -260 FC, it remains statistically insignificant.

The results from table 6 report also that ATT obtained using the ratio of per capita total consumption per day to poverty line (1\$) and that of poverty line (2\$) as outcome variables are both negative. The average effect of credit constraints ranges from -0.59 to $-0,48$ for the first and from -0.29 to -0.23 for the second. ATT obtained from the ratio of per capita total consumption per day to $1 \$$ of poverty line is significant at $\mathrm{p}<0.000$ under Radius and Stratification matching, $\mathrm{p}<0.005$ under Kernel matching and not significant under Nearest Neighbor matching. ATT obtained from the ratio of per capita total consumption to poverty line (2\$) is significant at $\mathrm{p}<0.000$ under Radius, $\mathrm{p}<0.005$ under Kernel and Stratification matching and not significant under Nearest Neighbor.

\section{DISCUSSION}

The provision of financial services to poor farmers in DRC, as is the case in a lot of developing nations, has often been perceived as difficult. The main difficulties in the financing of agriculture are related to the information problem, the high transaction costs, the low returns of agriculture and the high covariant risk. Maldonado [6] and González-Vega [5] reported that "several difficulties create existence problems (no access), increase the costs of access, and add to other market failures. Those difficulties are related to "(i) high transaction costs for both borrowers and lenders, which increase the cost of the loans beyond interest rates and depend on distance (physical, cultural, and social), (ii) information problems, which create uncertainty for the lender about the ability and willingness to repay of the borrower and may thus result in adverse selection and moral hazard, (iii) incentive problems, which emerge from the conflicting interests of lenders and borrowers and, under hidden information, may result in moral hazard, (iv) enforcement problems, which increase the costs for lenders, and (v) covariance problems, as the activities funded may be influenced by systemic shocks" [5].

Given the State banks' failure in credit provision, microfinance institutions have been considered as the new paradigm of rural finance and as a strong response to the difficulties of providing financial services (loan and deposit) to poor populations and especially smallholder farmers. The success of Asian and South American microfinance organizations has pushed many international development agencies to

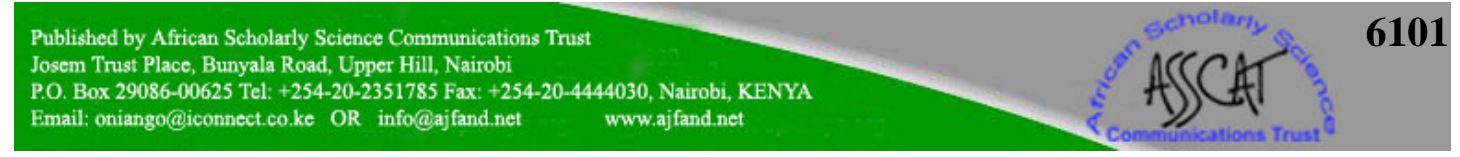


believe that microfinance is a new paradigm capable of contributing in an efficient way to the provision of credit towards poor farmers and thus to the reduction of rural poverty. This new lending technology resorts to non-traditional approaches to collateral requirements, such as the mechanism of supervision and collateral through village banking groups and allows a win-win institutional setting. The basic assumption of this new paradigm is that problems of information, which results in anti-selection problems, moral hazard, informational costs and barriers to access, are resolved, because the partners are well known given social and geographic proximity and social pressure.

Despite the proliferation of microfinance organizations operating in Kinshasa, the results of this study show that many farmers and poor populations in the Hinterland of Kinshasa continue to face limited access to credit. The results from subjective as reported by the respondents of the survey suggest that high risks related to agricultural activities and low returns, weak portfolio of microfinance, as well as the methodology of credit (collateral, high interest rates, non compatible loan terms and procedure) applied in microfinance remain the main constraints to the financing of agriculture. These results suggest that microfinance institutions in the Hinterland of Kinshasa are far from correcting the imperfections of the agricultural credit market and from the objective of increasing access to micro credit for the benefit of the poorest of the poor, notably poor farmers.

In the light of results from logit models, one could note that the characteristics related to household social capital endowment, to household human capital, to household financial capital and to household physical capital are the main determinants of credit constraints status. These characteristics provide information on household capacity to repay loan and coping strategy with high covariant risks. One could observe that the richest of the poor are less exposed to the risks of being credit constrained rather than the poor of the poorest. These findings confirm what has been reported in some previous empirical studies. These studies reported that the degree of poverty affects the response to credit, which is not intended for the poorest and most vulnerable [10, 19, 20, 21].

The results of impact evaluation conform to what has been argued and evidenced in literature from developing nations $[10,11,12,13,14,15,16,22,23,24,25]$ and support the paradigm of a virtuous sequence "micro credit - pro-poor growth poverty reduction", inspired from the paradigm of "financial liberalization, growth and poverty reduction. In terms of policy implications, the results suggest that the provision of credit towards poor farm households would contribute to the reduction of poverty and the improvement of their well-being.

\section{CONCLUSION}

This study investigates the effects of credit constraints on household's economic welfare in the Hinterland of Kinshasa. Given the counterfactual problem related to the impact evaluation, the Propensity Score Matching was applied to compute the impact. Household participation in off-farm activities, household participation in social and

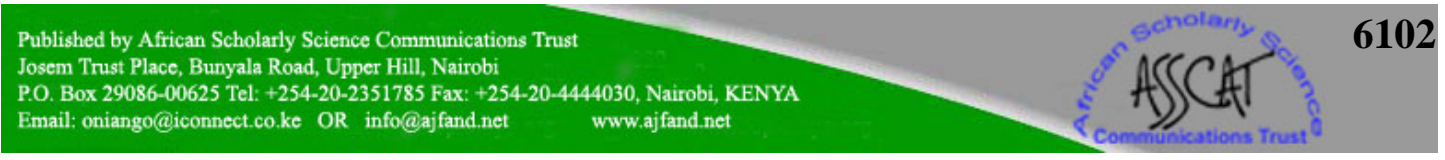




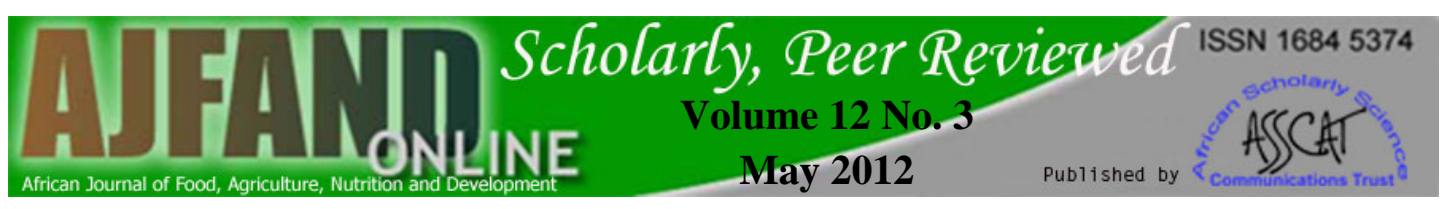

economic organizations, regular household access to remittances, land holding, household access to extension services and household size are found to be significant determinants of household credit constraints. In terms of policy implications, these findings suggest that rural and agricultural development policy aiming to promote farm household participation in off-farm activities, to improve a better access to agricultural advocacy and extension services, to enhance farmer access to land holding and social and economic networks could reduce the risks of credit constraints and thus remove the majority of constraints related to the financing of farm activities. Furthermore, a better remittance policy would reduce household credit constraints and improve the chances of obtaining credit. The findings also show that credit constrained households are estimated to have lower welfare outcomes than unconstrained households. Thus, the improvement of farm household credit access would enhance welfare distribution. This is only possible if the outreach of microfinance is improved and the lending technologies are innovated to meet the needs of poor farm households. 


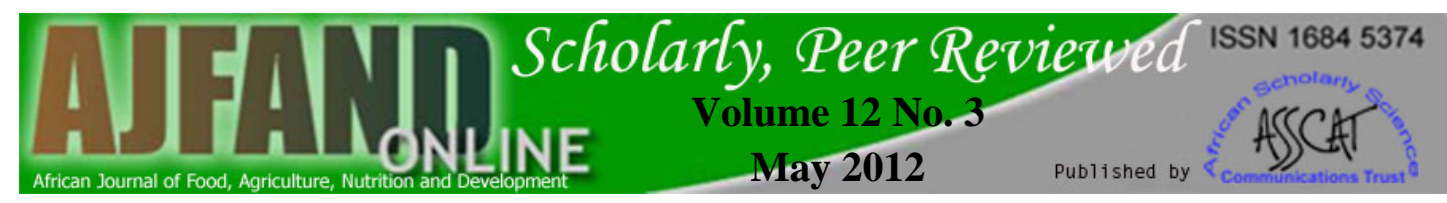

Table 1: Households characteristics (discrete variables)

\begin{tabular}{|l|r|r|r|r|}
\hline & Modality & $\begin{array}{r}\text { Credit } \\
\text { Constrained }\end{array}$ & OR (95\%) & P.value \\
\hline HHGENDER & Men (184) & 72.3 & $1.660(0.610-4.516)$ & 0.317 \\
& Women( 18) & 61.3 & & \\
\hline OFFFARM & Yes (82) & 59.8 & $0.391(0.209-0.729)$ & 0.000 \\
& No( 120) & 79.2 & & \\
\hline ASSOCIATION & Member (107) & 61.2 & $0.351(0.183-0.674)$ & 0.001 \\
& No member( & 78.6 & & \\
\hline ASSREMIT & Yes (85) & 61.2 & $0.428(0.320-0.797)$ & 0.007 \\
& No (117) & 78.6 & & \\
\hline LANDPROPETY & Yes (97) & 41.2 & $0.007(0.001-0.005)$ & 0.000 \\
& No (105) & 99.8 & & \\
\hline EXTENSION & Yes (102) & 46.1 & $0.002(0.008-0.009)$ & 0.000 \\
& No (100) & 97.0 & & \\
\hline MBAKA & Yes (69) & 69.0 & $0.880(0.466-1.667)$ & 0.697 \\
& No (133) & 72.2 & & \\
\hline DUMI & Yes (65) & 80.0 & $1.957(0.967-0.958)$ & 0.059 \\
& No (137) & 67.0 & & \\
\hline MENKAO & Yes (68) & 64.7 & $0.623(0.331-1.172$ & 0.141 \\
& No (134) & 74.6 & & \\
\hline
\end{tabular}

Table 2: Households characteristics (continuous variables)

\begin{tabular}{|l|r|r|r|r|r|r|}
\hline \multirow{2}{*}{ Variables } & \multicolumn{2}{|c|}{ Rationed } & \multicolumn{2}{r|}{ Non rationed } & \multicolumn{2}{|r|}{ Difference } \\
\cline { 2 - 7 } & Means & SD & Means & SD & Value & P.value \\
\hline SIZEH & 5.201 & 1.732 & 4.327 & 1.994 & 0.873 & 0.002 \\
\hline DRATIO & 0.503 & 0.230 & 0.511 & 0.265 & 0.007 & 0.832 \\
\hline EDUCHH & 9.368 & 3.853 & 9.586 & 3.947 & 0.218 & 0.717 \\
\hline HHAG & 44.996 & 9.434 & 45.189 & 10.766 & 0.196 & 0.897 \\
\hline SIZEF & 1.383 & 1.279 & 1.211 & 0.706 & 0.172 & 0.334 \\
\hline
\end{tabular}




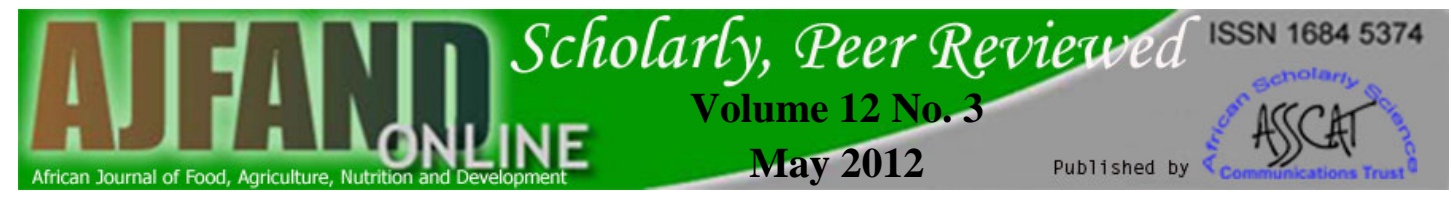

Table 3: Distribution of household welfare

\begin{tabular}{|c|c|c|c|c|c|c|c|}
\hline \multirow[t]{2}{*}{ Indicators } & \multicolumn{2}{|r|}{ Sample } & \multicolumn{2}{|c|}{ Constrained } & \multicolumn{2}{|c|}{ Unconstrained } & \multirow{2}{*}{$\begin{array}{r}\text { Difference } \\
\text { of means }\end{array}$} \\
\hline & Means & DS & Means & DS & Means & DS & \\
\hline $\begin{array}{l}\text { Per capita Food } \\
\text { consumption }\end{array}$ & 483.47 & 287.69 & 416.66 & 207.58 & 649.37 & 380.09 & $232.70 * * *$ \\
\hline $\begin{array}{l}\text { Per capita non Food } \\
\text { consumption }\end{array}$ & 237.20 & 236.55 & 202.12 & 141.9 & 324.28 & 368.86 & $122.16^{* * *}$ \\
\hline $\begin{array}{l}\text { Per capita } \\
\text { consumption per day }\end{array}$ & 785.94 & 464.47 & 680.69 & 322.41 & 1047.28 & 634.44 & $366.57 * * *$ \\
\hline $\begin{array}{l}\text { Per capita } \\
\text { consumption / } 560 \\
\text { FC (1\$) }\end{array}$ & 1.40 & 0.83 & 1.21 & 0.58 & 1.87 & 1.13 & $0.65^{* * *}$ \\
\hline $\begin{array}{l}\text { Per capita } \\
\text { consumption / } 1120 \\
\text { FC }(2 \$)\end{array}$ & 0.70 & 0.41 & 0.61 & 0.29 & 0.94 & 0.57 & $0.33 * * *$ \\
\hline
\end{tabular}

$* * *=$ Significant at $1 \%$ level 


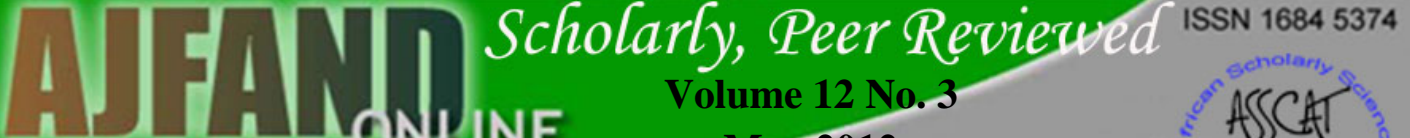

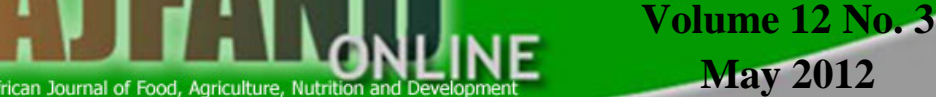 \\ May 2012

Table 4: Table: Results from Logit Model of Credit Constraints

\begin{tabular}{|l|r|r|r|r|}
\hline & & & & \\
\hline Variables & Coefficients. & \multicolumn{1}{c|}{ Std. Err. } & \multicolumn{1}{c|}{$\mathrm{z}$} & $\mathrm{P}>\mathrm{z}$ \\
\hline HHSIZE & 0.413 & 0.189 & 2.18 & 0.029 \\
\hline HHMAL & -105.032 & 0.976 & -1.08 & 0.282 \\
\hline HRATIO & 1.279 & 1.184 & 1.08 & 0.280 \\
\hline EDUCHH & -0.003 & 0.034 & -0.09 & 0.928 \\
\hline REMITTANCE & 0.081 & 0.080 & 1.02 & 0.308 \\
\hline ASSOCIATION & -0.341 & 0.581 & -0.59 & 0.557 \\
\hline OFFFARM & -1.466 & 0.672 & -2.18 & 0.029 \\
\hline LANDPROPERTY & -1.323 & 0.624 & -2.12 & 0.034 \\
\hline FARMSIZE & -4.487 & 1.103 & -4.07 & 0.000 \\
\hline EXTENSION & 0.312 & 0.314 & 0.99 & 0.321 \\
\hline MBANKANA & -3.382 & 0.847 & -3.99 & 0.000 \\
\hline DUMI & 0.659 & 0.699 & 0.94 & 0.346 \\
\hline CONSTANT & 1.274 & 0.807 & 1.58 & 0.114 \\
\hline Number of observations & 494.103 & 2.351 & 2.10 & 0.036 \\
\hline LR chi2 & 202 & & & \\
\hline Prob> Chi2 & 154.01 & & & \\
\hline Pseudo R2 & 0.000 & & & \\
\hline Log likelihood & 0.635 & & & \\
\hline
\end{tabular}

Table 5: Distribution of Propensity Score of being Credit Constrained

\begin{tabular}{|c|c|c|c|c|}
\hline Percentiles & & Smallest & & \\
\hline $1 \%$ & .0722119 & .0722119 & & \\
\hline $5 \%$ & .0722119 & .0722119 & & \\
\hline $10 \%$ & .1825988 & .0722119 & Obs & 195 \\
\hline $25 \%$ & .4041671 & .0722119 & Sum of Wgt. & 195 \\
\hline \multirow[t]{2}{*}{$50 \%$} & .9788712 & & Mean & .7368888 \\
\hline & & Largest & Std. Dev. & .3436655 \\
\hline $75 \%$ & 9983873 & .9998783 & & \\
\hline $90 \%$ & 9994375 & .9998783 & Variance & $.11810 €$ \\
\hline $95 \%$ & .9997383 & .999917 & Skewness & -.8369852 \\
\hline $99 \%$ & .999917 & .9999434 & Kurtosis & 1.985 .701 \\
\hline
\end{tabular}




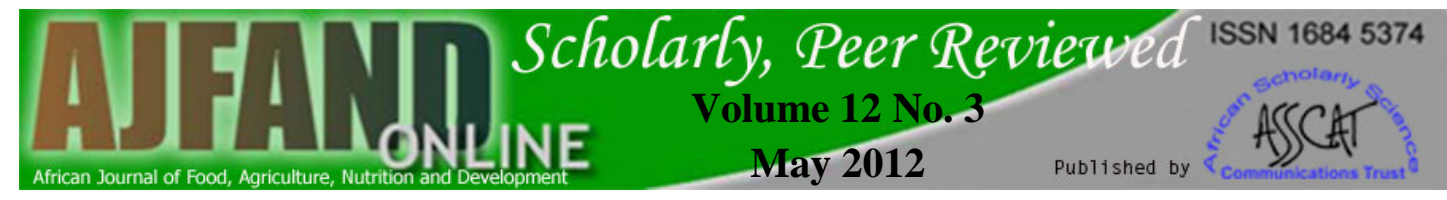

Table 6: Impact of credit constraints on economic welfare of constrained households

\begin{tabular}{|c|c|c|c|c|}
\hline Outcome variables & Methods & ATT & Std. Err & T-test \\
\hline \multirow[t]{4}{*}{ Per Capital total consumption per day } & $\begin{array}{l}\text { Nearest } \\
\text { neighbors }\end{array}$ & -259.877 & 171.983 & -1.511 \\
\hline & Radius & $-328.421^{* * *}$ & 115.097 & -2.853 \\
\hline & Kernel & $-268.773^{* *}$ & 126.859 & -2.119 \\
\hline & Stratification & $-279.533 * * *$ & 111.339 & -2.511 \\
\hline \multirow[t]{4}{*}{ Per Capita Non-Food Consumption per day } & $\begin{array}{l}\text { Nearest } \\
\text { neighbors }\end{array}$ & -63.503 & 63.44 & -0.985 \\
\hline & Radius & - 109.696* & 66.44 & -1.643 \\
\hline & Kernel & -61.252 & 63.498 & -0.965 \\
\hline & Stratification & -64.38 & 70.721 & -0.91 \\
\hline \multirow[t]{4}{*}{ Per Capita Food Consumption per day } & $\begin{array}{l}\text { Nearest } \\
\text { neighbors }\end{array}$ & - 197.373* & 106.398 & -1.855 \\
\hline & Radius & $-218.725^{* * *}$ & 69.947 & -3.127 \\
\hline & Kernel & $-207.521^{* *}$ & 96.062 & -2.16 \\
\hline & Stratification & $-215.153^{* *}$ & 90.183 & -2.386 \\
\hline \multirow[t]{4}{*}{$\begin{array}{l}\text { Ratio Per capita Total Consumption per } \\
\text { day to poverty line } 560 \mathrm{FC}(1 \$)\end{array}$} & $\begin{array}{l}\text { Nearest } \\
\text { neighbors }\end{array}$ & -0.464 & 0.357 & -1.299 \\
\hline & Radius & $-0.586^{* * *}$ & 0.185 & -3.17 \\
\hline & Kernel & $-0.48^{*}$ & 0.273 & -1.756 \\
\hline & Stratification & $-0.499 * * *$ & 0.194 & -2.568 \\
\hline \multirow[t]{4}{*}{$\begin{array}{l}\text { Ratio Per Capita Total Consumption per day } \\
\text { to poverty line } 120 \mathrm{FC}(2 \$)\end{array}$} & $\begin{array}{l}\text { Nearest } \\
\text { neighbors }\end{array}$ & $-0.232 *$ & 0.133 & -1.746 \\
\hline & Radius & $-0.293 * * *$ & 0.109 & -2.688 \\
\hline & Kernel & $-0.24^{* * *}$ & 0.11 & -2.187 \\
\hline & Stratification & $-0.25 * *$ & 0.104 & -2.401 \\
\hline
\end{tabular}

$* * *=$ Significant at $1 \%$ level; $* *=$ Significant at $5 \%$ level; $*=$ Significant at $10 \%$ level 


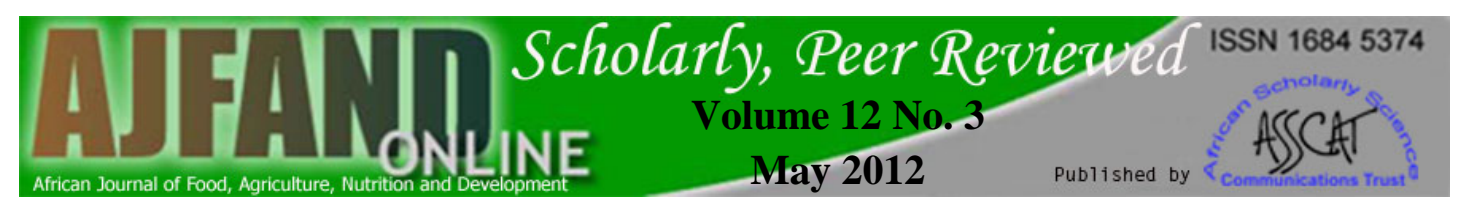

\section{REFERENCES}

1. Muayila K H Financement de l'agriculture paysanne par les organisations de microfinance. Déterminants de l'offre et la demande de micro crédit par les ménages agricoles dans la périphérie de Kinshasa, mémoire de master complémentaire, Université de Liège, Belgique.2006.

2. Nkwembe UGB Problématique des ménages agricoles ruraux et urbains dans la périphérie de la ville de Kinshasa, Essai d'analyse du phénomène et de ses implications sur la sécurité alimentaire, thèse doctorale, UCL, Louvain-laNeuve, Belgique. 2006.

3. PAM. Programme Alimentaire Mondial. Analyse globale de la sécurité alimentaire et de la vulnérabilité (CFSVA) en République Démocratique du Congo. PAM, Kinshasa. 2008.

4. PNUD. Programme des Nations Unies pour le Développement. Pauvreté et dynamique communautaire, Kinshasa, Bas-Congo, Bandundu. PNUD, Kinshasa. 2005.

5. González-Vega C, Rodríguez-Meza J, Southgate D and JH Maldonado Poverty, Structural Transformation, and Land Use in El Salvador: Learning from Household Panel Data. Principal Paper presented at the annual meeting of the American Agricultural Economics Association, Denver Colorado, August 1- 4, 2004.

6. Maldonado JH Relationships among poverty, financial services, human capital, Risk coping and natural resources : Evidences from El Salvador and Bolivia, doctoral Dissertation, Department of Agricultural, Environment and Development Economics, Ohio State University. 2004.

7. Rosenzweig $\mathbf{M}$ and KI Wolpin Credit market constraints, consumption smoothing, and the accumulation of durable production assets in low-income countries: Investments in bullocks in India. Journal of Political Economy. 1993; 101: 213-224.

8. Pischke VJD Structuring credit to manage real risks. In: Bouman FJ and O Hospes (Eds.). Financial Landscapes Reconstructed, West view Press, Boulder, Colorado. 1994.

9. Zeldes SP Consumption and liquidity constraints: an empirical investigation. Journal of Political Economy. 1989; 97: 305-346.

10. Coleman B The Impact of Group Lending in Northeast Thailand. Journal of Development Economics. 1999; 60:105-141.

11. Khandker S Fighting Poverty with Micro credit: Experience in Bangladesh, Oxford, Oxford University, 1998.

12. Khandker $\mathbf{S}$ and $\mathbf{R}$ Faruquee The impact of farm credit in Pakistan. Agricultural Economics. 2003; 28: 197-213. 
13. Khandker S Does Microfinance Really Benefit the Poor? Evidence from Bangladesh. Paper delivered at Asia and Pacific Forum on Poverty: Reforming Policies and Institutions for Poverty Reduction. Asia Development Bank, Manila, 2001.

14. Pitt $\mathbf{M}$ and $\mathbf{S}$ Khandker The Impact of Group-Based Credit Programs on Poor Households in Bangladesh: Does the Gender of Participation Matter?. Journal of Political Economy. 1998; 106: 958-996.

15. Toshio K Impact of Microfinance on Rural Household in the Philippine, Asian Development Bank. 2007.

16. Wright G Microfinance systems: designing quality financial services for the poor. Zed Books Ltd. London \& New York, and the University Press. Limited, Dhaka. 2000.

17. Becker SO and A Ichino Estimation of average treatment effects based on propensity scores. Stata Journal. 2002; 2: 358-377.

18. Rosenbaum $\mathbf{P}$ and $\mathbf{D}$ Rubin The central role of the propensity score in observational studies for causal effects. Biometrika. 1983; 70: 41-55.

19. Hulme $\mathbf{D}$ and $\mathbf{P}$ Mosley Finance for the Poor or Poorest? Financial Innovation, Poverty and Vulnerability. In: who needs credit?, Geoffrey D, Wood I, Sharif A and University Press Ltd (Eds), Poverty and Finance in Bangladesh, 1997.

20. Morduch JH Does Microfinance Really Help the Poor? New Evidence from Flagship Programs in Bangladesh. New York University: New York. 1998.

21. Navajas S, Schreiner M, Meyer RL, Gonzalez-Vega $\mathbf{C}$ and J RodriguezMeza Micro credit and the poorest of the poor: theory and evidence from Bolivia. World Development. 2000; 28: 333-346.

22. Zaman $\mathbf{H}$ Assessing the Poverty and Vulnerability Impact of Micro credit in Bangladesh: A case Study of BRAC, World Bank. 2000.

23. Aroca P Microcredit Impact Assessment: The Brezilian and Chilean Cases, IDEAR, Universidad Catolica del Antofagasta. 2002.

24. Arun T, Imai $\mathbf{K}$ and $\mathbf{F}$ Sinha Does the microfinance reduce poverty in India? Propensity Score Matching based on a National-level Household Data. Development Economics and Public Policy Paper Series, 17. University of Manchester: Manchester. 2006.

25. Negash Z Microfinance Loan Delivery, Utilization and Impact: with specific reference to Tigray, Nord Ethiopia, doctoral Dissertation, Division of Agricultural and Food Economics, Katholieke Universiteit Leuven. 2008. 